Proceedings of the Institution of
Civil Engineers
Management, Procurement and Law
163
February 2010 Issue MPI
Pages $17-28$
doi: $10.1680 / \mathrm{mpa} / 2010.163 .1 .17$
Paper 700021
Received 01/10/2007
Accepted I $2 / 08 / 2009$
Keywords:
contracts \& law
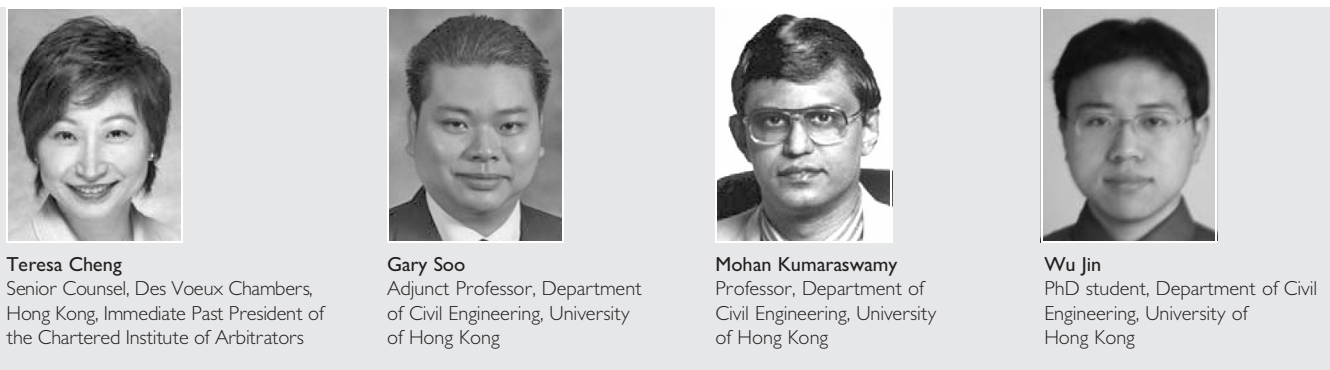

\title{
Security of payment for Hong Kong construction industry
}

T. Cheng BBS, SC, JP, BSc(Eng), AKC, LLB, CEng, CArb, FICE, FCIArb, FHKIArb, FSIArb, G. Soo BSc, LLM, CEng, MICE, MIStructE, MHKIE, MASCE, FCIArb, FHKIArb, M. Kumaraswamy MSc, PhD, MASCE, MIEAus, MCIArb, FICE, FIESL, FCIOB, FHKIE, FHKICM and W. Jin MA

In Hong Kong, getting paid is not always easy and the construction industry stands as an illustration of how much effort may be needed to achieve this and how adverse impacts can escalate from payment problems. At the moment, many jurisdictions have adopted some form of legislation or practical measures to enhance the ease and security of payment in the construction industry.

Experience and insights from their operations provide guidance to Hong Kong for its way forward. By studying practices and feedback in other jurisdictions, this paper outlines and reviews the options and alternatives implemented for securing payment in the construction industry in Hong Kong. In addition, it also seeks to appraise their respective practicability for Hong Kong and highlight those areas to be considered if they are to be adopted or adapted for use in the Hong Kong construction industry. The ultimate aim is to provide an objective, balanced and reasoned overview for further study and discussion among stakeholders in the Hong Kong construction industry when moving forward. This is not intended to be an exhaustive review of all means adopted to achieve security of payment but aims to discuss those methods which are more likely to be suitable to be adopted in Hong Kong in the light of the circumstances and environment prevailing there.

Furthermore, this study did not investigate the many modes of procurement that are available and which may address the concern of security of payment but focuses on the traditional form of contracts in use in Hong Kong. Public-private partnerships or private finance initiatives which would call for different discussions are not covered.

\section{INTRODUCTION}

In the late 1990s, after the exposure of several non-compliant construction incidents in Hong Kong that prompted widespread public concern, all stakeholders in the construction industry took up the chance to take a critical review of the practices and culture of the industry and explored paths for reform. In April 2000, the chief executive of the Hong Kong Special Administrative Region appointed the Construction Industry Review Committee (CIRC) to comprehensively review the current state of the industry and to recommend improvement measures. The output was published in 2001 in the report entitled Construct for Excellence: Report of the Construction Industry Review Committee (CIRC, 2001).
The Hong Kong construction industry has several features described that are not uncommon in construction industries elsewhere. In the Hong Kong CIRC report, it is stated

Local construction activities are labour-intensive, dangerous and polluting. Built products are seldom defect-free. Construction costs are comparatively high. The industry is very fragmented and is beset with an adversarial culture. Many industry participants adopt a short-term view on business development, with little interest in enhancing their long-term competitiveness. There is a tendency to award contracts to the lowest bidders and delivery programmes are often unrealistically compressed. Accountability is undermined by the prevalence of nonvalue adding multi-layered subcontracting and lax supervision. An inadequately trained workforce also impairs the industry's ability to adopt new technologies and to cope with new challenges.

As observed in the report, the delivery of a construction project is a highly complex process, involving multi-disciplinary inputs provided by a vast number of participants from tradespeople, technicians, supervisors, professionals, consultants, contractors and subcontractors, to employers and the authorities. A number of common key problems were also identified. Those relating primarily to payment problems are the lack of a more employerfocused approach, the tendency to award contracts to lowest bidders, the short-term attitude to business development, the non-value-adding multi-layered subcontracting, declining productivity growth and high building costs, and the fragmentation and adversarial culture within the industry.

A total of 109 recommendations were made in the report in almost every aspect of the construction industry. In answer to these, the Provisional Construction Industry Co-ordination Board (PCICB) was established on 28 September 2001 to spearhead industry reforms and to propagate a new culture of change. In February 2007, the new Construction Industry Council was established to take the matters forward.

Indeed, many of these problems stem from long-established practices and processes and arise out of certain inherent features of the Hong Kong construction industry. The construction industry can be characterised as an amalgamation of a multitude of chained operations, often with limited and unsecured capital backing. Construction activities are often subject to a high level of technical and economic risks. Tender prices are typically prepared in a limited time period and inserted with intangible uncertainties on the basis of technical 
and financial assumptions which affect the ultimate pricing. Contractors are paid in arrears. The typical interim payment arrangements result in work being paid for at least 2 months after execution. Advanced capital funding for the works by overdrafts, trade credits or other interim means as the works progress become unavoidable. Subcontractors are often engaged to reduce the risk or need for such advance funding. Multilayering subcontracting becomes a common phenomenon. In the end, the toil and sweat of the workers usually provide a significant contribution to the capital that has to be advanced for the completion of the works.

Most, if not all, of the contractors are unsecured creditors of the parties for whom they have contracted to work. Contractors do not have a lien over the property they have built even if they are unpaid and the contractual licence granted to them to remain on site can be revoked by the project owner at any time so long as an undertaking as to damages is provided when an injunctive relief from the court is obtained. Hence, cascade of payments from the project owners from the top downward, all the way to the workers, is critical for the cash flow to all concerned and livelihood of the workers. Cash flow management is essential to the survival of contractors and subcontractors. The business viability of contractors and subcontractors depends more upon cash flow than profit margins. The existence of a stable and healthy labour market is also dependent on the cash flow emanating from the employers.

More importantly, it is the prospects of prompt payment for completed works that offer a strong incentive to contractors and subcontractors to deliver quality service (CIRC, 2001). Under the current arrangement, if payments are not forthcoming from the employer to the contractor, all lower-tier subcontractors, suppliers and workers would suffer. Further, subcontracts typically provide for 'pay-when-paid' or 'back-to-back' arrangement for progress payments. Thus, even when payments have been promptly effected by the employer to the contractor, there is no effective means to ensure that such payments can flow down through the subcontractors to the workers. Any diversion of monies received under the project for other purposes by a party along the chain would result in an interruption of the cash flow, leaving the lower-tiered subcontractors and workers at peril.

Without the certainty and security of timely and fair payments for works done or materials supplied, problems in other aspects of the works such as quality, delay and safety, etc. are highly likely to arise. Without an effective mechanism to ensure the uninterrupted cascade of payment down the chain and for any such interruption of payment to be detected in time, any measure of security of payment may still be of no use to the construction industry as a whole.

As so aptly pointed out in the Guide to Best 'Fair Payment' Practices, published by the UK Office of Government Commerce in July 2007 (OGC, 2007)

Poor payment practices in the construction industry give rise to substantial additional financing and transaction costs. More importantly certainty over how much and when payment is made builds trust between supply team members and underpins collaborative working to achieve value for money projects for clients.
Security of payment is fundamental to developing a healthy, professional and competitive construction industry. Here, security of payment is a term used by the building and construction industry to describe the need for secure, long-term guaranteed arrangements for payments for work performed or materials supplied.

\section{MECHANISMS FOR SECURITY OF PAYMENT: AN OVERVIEW}

To achieve security of payment, legislation has been enacted to deal with payment-related issues in construction contracts in many jurisdictions outside Hong Kong. Some other jurisdictions have adopted industrial or administrative measures to help provide security of payment in the construction industry.

\section{I. Administrative measures}

A recent example of such administrative measure is provided by mainland China via the introduction of payment bonds and other types of bonds in construction contracts, testing these as pilot schemes in several cities. Another example is Sri Lanka, where the use of bid bonds, performance bonds, advance payment bonds and maintenance bonds are quite common and there is a scheme established by the Sri Lankan government called 'Construction Guarantee Fund' which enables domestic contractors to obtain bonds and guarantees at concessionary terms.

\subsection{Legislative measures}

The first of the security of payment legislation is the UK Housing Grants, Construction and Regeneration Act 1996. Other examples include the Building and Construction Industry Security of Payment Act 1999 in New South Wales; the Building and Construction Industry Security of Payment Act 2002 in Victoria; the Building and Construction Industry Security of Payment Act 2004 in Queensland; the Construction Contracts Act 2004 in Western Australia; the Construction Contracts Act 2002 in New Zealand; and the Building and Construction Industry Security of Payment Act 2004 in Singapore. In Malaysia, a legislative move towards the enactment of the Construction Industry Payment and Adjudication Act 2007 is also being finalised. These legislations generally enable progress in claims for payments in construction contracts even if the contract itself is silent on it, and they commonly contain provisions for prompt adjudication of disputes over progress payments, allowing suspension of works for non-payment or failure to provide security after adjudication, and illegalising or outlawing conditional payment provisions in construction contracts. These legislative measures are intended partly to ensure that money flows down the contracting chain by banning pay-if-paid/pay-when-paid clauses. These clauses allow the contractor to a contract to avoid paying for work done under the contract simply because the contractor has not yet been paid under a separate contract. In many ways, such provisions essentially defeat the privity of contracts and stop subcontractors from getting money to which they are legitimately entitled for works they have done competently and to the best of their abilities. There is good reason for support for the protection of the subcontractors who have actually executed the works by banning these conditional payment clauses in various jurisdictions, as explained in the explanatory memorandum to the Western Australia Construction Contracts Bill 2004 (Aust LII, 2009). 


\subsection{The way forward for Hong Kong}

In Hong Kong, the CIRC (2001) report recommended in para. 5.80 that 'further consideration should be given to the merits of, and the need for, enacting security of payment legislation having regard to local circumstances and in the light of overseas experience'. Following this, there was a pilot implementation of voluntary adjudication and dispute resolution adviser system in a number of designated government projects. Although the merits of such legislation overseas were acknowledged, relying on the experience of such pilot schemes, it was remarked in 2005 by the Hong Kong government, at least for the public sector projects, that security of payment legislation is unnecessary under local circumstances for the moment. Instead of adopting security of payment legislation generally, it was reported that other measures for dealing with the dubious practices in the private sector, such as promulgation of guidelines on security of payment and setting up of trust accounts for payment to subcontractors, could be considered. The newly formed Construction Industry Council is expected to further deliberate on the subject of security of payment accordingly.

Those who are in support of some form of security of payment legislation for Hong Kong have reservations as to the effectiveness of the mere use of such administrative measures in easing cash flow difficulty. For example, promulgation of guidelines on security of payment does not have the same mandatory effect on the parties; the setting up of trust accounts for payment to subcontractors may be of more relevance to payment problems that are resulted from insolvency. As for the use of voluntary adjudication, a party to a voluntary adjudication may always refuse to have adjudication; the adjudication process itself, being quite similar to a mini-arbitration, can indeed take a long time. It is further recognised that some modifications may be required when adopting such overseas legislation to suit the local conditions. On the other hand, those in support are of the view that such legislation, even in a limited form, can be of benefit, not limited to contractors and subcontractors, but rather to the whole of the Hong Kong construction industry.

It is nonetheless worth noting that the security of payment legislation overseas has been in a stage of review based on their respective operation experience. Other measures introduced or in use for securing payment in some jurisdictions are also the subject of experiments and study. Examples of these include the consultation paper entitled Improving Payment Practices in the Construction Industry: 2nd Consultation on Proposals to Amend Part II of the Housing Grants Construction and Regeneration Act 1996 and the Scheme for Construction Contracts (England and Wales) Regulations 1998, published in June 2007 by the UK Department of Trade and Industry (DTI, 2007); and the discussion paper entitled Security of Payments in the Building and Construction Industry in October 2002 published by the Royal Commission into the Building and Construction Industry in Australia (RCBCI, 2002). These all provide Hong Kong with excellent insight and real-life guidance on the practicability and effectiveness of these legislation and measures, allowing the construction industry to explore whether and if so how to adopt or adapt them for use in Hong Kong.

The way forward is still a matter yet to be seen. In the premises, an outline and reviews of the choices available and suggestions for enhancing security of payment are provided below, with a view to providing an agenda for discussions of their respective pros and cons, practicability, limitations and ease of implementation and enforcement for use in the Hong Kong construction industry.

\section{GETTING THE CONTRACT RIGHT}

Before venturing into discussing possible legislation or other administrative measures, it is always important not to lose sight of the vital starting point - the contract itself. Without a clear contractual framework, legislative or administrative measures to enhance security of payment, whether from the perspective of timelines or quantum, may be of little utility. This is true for contractors and subcontractors; this is likewise true for construction workers.

\section{I. Written contracts}

It is well known that many subcontractors in Hong Kong, especially those at the lower tiers in a multi-layered subcontracting chain, do not enter into formal subcontracts with the main or upper-tier contractors. The contract may only be partly written; it may engage uncertain arrangements such as back-to-back without specific definition being given; it may even be made wholly orally. Apart from project requirements, other matters such as rules for measurement and methods of valuation of variations are often not discussed let alone documented. This practice poses difficulty for certainty of the payment amount, let alone prompt payment. In many cases, apart from disputing over performance or valuation of work, parties argued on the existence or wording of a term or even about who is the actual contracting party. The matters are further complicated by the possible deductions by way of set-off under the same contract, across contracts or at common law; by the incorporation of 'pay-when/if-paid' arrangement in subcontracts; and by the incorporation of arbitration clauses of the upper-tier contracts into subcontracts.

The need for a written contract is stressed in paragraph 2.2 of the Guidelines on Subcontracting Practice, which was published in March 2003 by the Hong Kong Provisional Construction Industry Co-ordination Board (PCICB, 2003) in response to the recommendation made by the Hong Kong CIRC aiming to raise the performance standards of subcontractors by providing them with a conducive environment to develop more effective collaboration and achieve better built quality, where it states that '[s]ubcontracts executed at all layers should be made on written documents for the sake of better transparency and more effective safeguard of legal rights and obligations'. The guidelines call for the clear definition of the method to ascertain interim and final payments under subcontracts. To achieve this, it is recommended that there should be provisions in subcontracts to cater for fair and timely payments for the amount of works completed; clear and equitable arrangements on deduction of payments that set out the grounds on which deductions may be made from payments due to subcontractors; identification, valuation and payment for variations to subcontract works; early settlement of final account; the rights of subcontractor in case of non-payment or late payment, such as suspending execution of works and referral to adjudication, mediation and arbitration; the contractual entitlement of subcontractors to recover reasonable interest on delayed payment; commitment by subcontractors to make timely payment of wages to their workers and subcontractors in lower tiers, as well as actions that could be taken against failure to do so; and percentages of payment to be deducted as retention 
money, which should be released fully upon fulfilment of obligations under the subcontracts (PCICB, 2003).

The Guidelines on Standard Forms of Domestic Subcontracts for Basic Trades published by the PCICB in May 2005 which incorporates these provisions can be a useful model to be adopted to provide the essential contractual framework for payments (PCICB, 2005).

It is noteworthy that, in some jurisdictions, statutory regulations as to the content of contracts are not uncommon, particularly where in deserving circumstances such as protection of consumers. This is notwithstanding that party autonomy to contracts has long been respected in various common law jurisdictions. An example, not directly related to security of payment, can be found in New South Wales. The New South Wales Home Building Act 1989 called for certain compulsory content for home building contracts between home owners and builders. The New South Wales Office of Fair Trading has produced a contract checklist of 12 questions in total to help home owners to decide whether they are ready to enter into such contracts (New South Wales Office of Fair Trading, 2005). The focus of its operation is obviously to protect home owners who deal with builders as consumers. Hence, it seems that, where the circumstances so justified, statutory intervention to assist parties as regards the proper content on certain aspects of a contract, such as payment, is an option on top of merely issuing guidance on industry best practice. Of course, any form of legislative intervention has to be balanced against the well-recognised and respected principle in a free market of party autonomy in contracts. If the imbalance of negotiating power or abuse of dominant position is such that the industry should no longer tolerate, legislative intervention may well be the only recourse.

\section{PAYMENTS TO CONTRACTORS/ SUBCONTRACTORS}

In other industries, there are various commercial devices commonly adopted to help in securing payments. Examples of these include the use of parent company guarantees or collateral warranties, or the adoption of counterparty risk assessment practice. The real question is whether such devices can be usefully applied in Hong Kong to secure payment from the employer or upper-tier contractors.

To achieve fair and prompt payment, a number of measures have been utilised in jurisdictions outside Hong Kong. The discussions here will focus only on those that are more likely to be of utility in Hong Kong and is not intended to be an exhaustive examination of all available forms of security of payment measures. As regards contractors and subcontractors, these include the introduction of payment bonds and the enhanced use of escrow account for retention money. They have been devised to ensure works done would be paid for. Another aspect is to ensure prompt payment by reinforcing certainty in interim payments so as to maintain cashflow. As illustrated below, for these to be effective, an initiative and a top-down arrangement from the employers is called for.

\section{I. Certainty of available fund to honour payment obligations}

4.1.1. Payment bond. In the context of the construction industry, a payment bond is an agreement by a surety towards a contractor that the surety will pay to the contractor the amount of works done under the construction contract, up to the bonded amount or a percentage of the price of the works done, in case the employer defaults in its payment obligations. The surety, who is usually a bank or insurance company, agrees to provide such a bond in return for a premium paid to it. A payment bond is similar in nature to a performance bond, which is to be provided by a contractor, but it secures payment obligations by the employer rather than performance obligations by the contractor under the contract. A payment bond can be used to secure payments from a contractor to its subcontractors or suppliers. Likewise, a payment bond can also be utilised to secure payment from the employer to the contractor.

(a) United States and Canada (payment bond procured by the Contractor). This is commonly used in private projects in the USA (34 states) and Canada where a contractor is required under the contract with the employer to provide a payment bond to secure its payment obligations towards its subcontractors and suppliers. The rationale for that is to enable the project to be free from the mechanics lien (a feature provided by mechanics' lien legislation in Maryland, United States starting from 1791) that the unpaid subcontractors or suppliers may otherwise assert over the project. In other words, a payment bond has the effect of protecting the employer against the possible financial loss caused by mechanics' lien. For public projects, mandatory payment bonds are used to protect subcontractors and suppliers. These legislations are often referred to as the Miller Act and the Little Miller Acts. An overview for these can be seen at the final report titled Builders' Liens in Nova Scotia: Reform of the Mechanics' Lien Act in June 2003 by the Law Reform Commission of Nova Scotia and the California Law Revision Commission (LRCNS, 2003).

The question may arise as to whether lien legislation should be introduced in Hong Kong. Mechanics' lien types of legislations are not found in some common law jurisdictions such as United Kingdom, Australia, New Zealand, Singapore and Hong Kong. In Australia, for example, a similar but different alternative is adopted. Rather than having lien on the real property involved in the projects, the New South Wales Contractors' Debt Act 1997 (and likewise in Queensland) provides a mechanism to allow unpaid persons or subcontractors to recover outstanding debts from a person further up the chain of contractors and the court, can make an attachment order against that defaulting contractor and, with the order, money owed by the principal to the defaulting contractor under the contract will be frozen pending judgment being given in the proceedings between the unpaid person and the defaulting contractor. The reasons why these mechanics lien legislations were introduced to the USA and Canada may be of historic or academic interests. It is submitted that mechanics' lien legislation is probably more a result of legislative public policy to protect the contractors and its lowertier subcontractors and suppliers, resulted from historical development in the USA. Nonetheless, from the practical perspectives, the experiences for using them are not all positive either. So far as ensuring cash flow down the project is concerned, the statutory lien remedy has become disproportionately expensive and complex to enforce; the lien legislation in the United States does not really address issues of time of payment and disputes over performance of contracts; more importantly mechanics' lien are enforced exclusively through judicial foreclosure sales of the property, which is a very drastic move for 
those at the lower tiers and of immense significance to the property owner who may be entirely faultless. It is a draconian measure that is only to be used if all else fails.

The use of payment bonds is nonetheless not free from complications. The bond is furnished to the employer, but the employer has no right to file a claim under the bond nor to call the bond. The beneficiaries are typically all the lower-tier subcontractors and suppliers. Hence the subcontractors and suppliers have to rely on the assistance from the employer in securing a copy of the bond in order to file a claim under it. Although it is in the employer's interest to know whether and how much has been claimed under the bond, that tends to get the employer involved in the payment disputes between the contractor and subcontractors. The other inevitable commercial implication is that the need for a bond would certainly be reflected in the tender price to be shouldered by the employer at the end of the day.

(b) Mainland China (payment bonds procured by employer). Another recent experience in using payment bonds to secure payment to contractors can be found in mainland China. A report on the implementation of construction law submitted to the fifth session of the tenth National People's Congress standing committee in 2003 (MCPRC, 2003) indicated that investors of construction projects across mainland China owed a total RMB336. 5 billion (US $\$ 40.69$ billion) to construction companies by 2002 . Some $39 \cdot 6 \%$ of the money in arrears took place in real estate development projects and $26 \cdot 7 \%$ in government-funded construction projects. It was further reported that late payment for construction had become prevalent in the industry and was worsening. An overview of these problems can be found in various documents, such as the Notice of the General Office of State Council on Resolving Payment Delay and Default Problems in the Construction Sector in November 2003 (SCPRC, 2003) and the Notice of General Office of State Council on Forwarding the Opinions of Ministry of Construction and Other Departments on Further Resolving Payment Delay and Default Problems in the Construction Sector in October 2004 (SCPRC, 2004). Following the determination from central government to resolve payment problems, the State Council introduced various measures to change the procurement practice in the construction industry and to overcome difficulties in getting paid. One of these measures is the use of payment bonds to be procured by the employer.

\section{As early as the Notice of the General Office of State Council} Office on Resolving Payment Delay and Default Problems in the Construction Sector, issued in November 2003, the use of payment bonds from employers was being advocated as part of the risk management measures to avoid payment problems from the very top. Since then, the use of payment bonds in mainland China started developing rapidly.

In August 2004, the PRC Ministry of Construction issued the Several Provisions on Implementing Construction Contract Guarantee in Real Estate Development Projects (For Trial Implementation) (MCPRC, 2004). Chapter 2 requires payment bond to be issued by the employer in favour of the contractor in every construction contract for real estate developments where the contract price exceeds RMB10 million (US \$1.46 million). The payment bond can be given in the form of a guarantee by a bank or a professional surety company at the time when entering into the construction contract. The amount of the bonded sum should be the same as that of the performance bond that the contractor is required to provide to the employer, and should be within the range of 10 to $15 \%$ of the contract price. The payment bond and the contract have to be submitted to the relevant construction authority for record. In 2005, several cities, namely Shenzhen, Xiamen, Qingdao, Chengdu, Hangzhou, Changzhou and Tianjin were chosen as pilot cities for the implementation of the use of payment bonds. Samples of such payment bond were also prepared and published in May 2005. Other cities and provinces, such as Beijing, Chongqing and Jiangsu, also issued their own regulations and measures for implementing the use of bonds in local construction contracts. As an illustration, in the case of Zhuhai, use of bonds is required for construction contracts with a price over RMB2 million (US \$293 000).

Studies on the experience of these pilot and pioneer cities all reported positively on the use of payment bonds in helping to reduce the payment problems (see Deng and Wang, 2006). After a review of the experience, in December 2006, the Ministry of Construction issued the Notice on Opinion on Further Implementing Construction Contract Guarantee (MCPRC, 2006), affirming the benefits of the use of payment bonds and extending its use to other pilot cities. It also sets out a target for establishing the systems for proper legal regulation, credit management, risk management and industrial regulation by 2010 in relation to the use of bonds in the construction industry.

(c) Hong Kong. For Hong Kong, there are good reasons for engaging the use of payment bonds to secure payment from an employer to the contractor and, likewise from a contractor to its subcontractors. Unlike other jurisdictions with builders' lien legislation, there is no lien at common law of a contractor for the works it has carried out over the project land, building or structure. As noted above, a lien is a charge, or claim, which one person has upon the property of another as security for the payment of a debt. Builders' lien legislations would grant people who have performed work, provided services, or furnished materials in relation to land, buildings or other structures with a lien upon the real property improved by the lien holders' efforts. However, the draconian effect of such legislation should be carefully analysed before embarking on it. If the use of payment bonds can address the problem of securing available funds for payment, lien legislations should probably be avoided.

In Hong Kong it is not uncommon for a construction contract of billions of dollars in value to be entered into between the contractor and the 'employer', which is a mere US $\$ 2$ shell company packaged as a management company but actually owning no assets at all other than the two US\$1 shares. This phantom 'employer' is often an affiliate/associated company of the land owner operating as a project management company set up by the land owner. In such a case, the true 'employer' can take the benefits of the corporate veil and can avoid liability towards the contractor for any payments due. After substantial completion of the work, the incentives for settling the outstanding claims by or payments due and owing to the contractor may not be there. The phantom 'employer' being one without any significant assets may become expendable after the completion of the work. 
From another perspective construction projects typically involve a pyramid-like structure of independent contracts, with the employer at the top, and at the bottom the construction workers. Given the number of contractual relationships that a construction project typically involves, the failure of any one of the parties along the chain can negatively affect those lower in the construction pyramid. Furthermore, generally, payments are made as the works progress and some form of advance capital funding for the works for a period prior to getting paid is inevitable. Hence, akin to a letter of credit in sale of goods contracts, a guarantee that there are funds for paying the works done and materials supplied is not unreasonable. If no payment is forthcoming from the top, all in the construction pyramid would suffer. This puts the contractor in difficulties since, while not getting paid, it has incurred liabilities towards its subcontractors, suppliers and workers.

It seems from the experience of mainland China that the use of payment bond is helpful. It also seems to be a fair practice as construction contracts in Hong Kong do usually require the provision of a performance bond from a surety procured by the contractor for the benefits of the employer. A payment bond procured by the payer as security for its payment obligations is just a reciprocity arrangement.

To minimise the commercial impact on the party procuring the bond, it can be a revolving bond for interim payments. If complemented with immediate dispute resolution mechanisms on interim payments, the employer or upper-tier contractor would not be able to evade payments even without the need of legislative measures to enforce decisions. It can also be used together with milestone payment arrangements. This is dealt with further below.

4.1.2. Parent company guarantee. Parent company guarantees are often required as a condition to submitting tender if the contractor is a subsidiary or joint-venture company of a large group of companies and there is evidence and hence confidence in the financial viability of the parent company. The exact scope of protection provided would obviously depend on the wordings used but, in general, the effects of such guarantees, like performance bonds, are to provide security or indemnity to employers in relation to the due performance by contractors.

The use for parent company guarantee, from a 'phantom' employer (as discussed above) to a contractor, may only be of use if it has the same ease of enforcement and security as a payment bond where the surety is usually an independent third party. Nonetheless, if appropriately worded, a parent company guarantee may be utilised to secure payment. This may be more amenable to the employer as it does not 'cost' them anything if its subsidiaries comply with its contractual obligations.

4.1.3. Others. Collateral warranties are regularly used to deal with the absence of contractual links among the numerous parties involved in construction projects, for example by rendering the contractor liable to the employer for design services provided by subcontractors; the beneficiaries under such warranties are normally not the subcontractors or workers down the line. Similarly, other devices such as advance payment guarantees to secure the advance payment effected to the contractor to meet its mobilisation or initial costs are typically engaged in international contracts to protect the employer against the failure of the contractors but not vice versa.

The use of counter-party risk assessment in the financial or commodity trading sectors has proved to be successful in varying extent. The process of counter-party risk assessment is a combination of professional good practices for due diligence investigation, for instance by checking matters such as track records, reputation in market, financial statements, credit status, etc. Nonetheless, in the construction industry, such due diligence investigation may not always turn out to be effective to deal with payment problems due to the inherent performance complications and legal uncertainties involved in the execution of construction works. The fact that the counterparty does not pay may have nothing to do with its financial viability. More importantly, this is unlikely to be viable in the Hong Kong situation at this date and time.

\subsection{Escrow account for retention}

The practice of retention is widespread among various common law jurisdictions, including Hong Kong. In many standard forms of construction contracts in Hong Kong, the payer (employer or upper-tier contractor) is permitted to retain a stipulated percentage of the progress payments that have become due, up to a ceiling amount. These are to be released in tranches, usually at substantial completion and at expiration of defects liability period/certificate of making good defects. Standard forms of contract usually require the employer to hold such retention on trust for the contractor, primarily as security for completion and rectification of works. A good analysis of retention moneys is provided in the guidance entitled Retentions: Striking out Cash Retentions published in September 2007 by the National Specialist Contractors Council in the UK as part of the Fair Payment Campaign (NSCC, 2007). Similar retention arrangement is also in place between the contractor and nominated subcontractors.

Under most standard forms of contract, the employer is deemed to be holding the retention money in a fiduciary capacity as a trustee for the contractor. Hence, in such situations, the contractor is entitled as a matter of law to request the employer to pay the present and future retention money into a separate trust account, for the benefit of the contractor. This is illustrated in the case of Concorde Construction Co Ltd v. Colgan Co Ltd, where a mandatory injunction was granted directing the employer to do so. The advantages of this injunction are obvious. The primary purpose is to offer some protection to the contractor in case of insolvency of the employer or breach of trust by the employer in wrongfully dissipating such sums against the interest of the beneficiary.

It should be noted that there can be no trust created unless the trust property is identified, and hence no trust is created if the retention money is left mixed with the employer's and the upper-tier contractor's own money. Nevertheless, there is usually no provision in the standard construction contracts in Hong Kong setting out how this contractual obligation is to be implemented by the employer or upper-tier contractor. The contract is silent as to where the retention should be held or by whom. Even if the retention is kept in a separate trust account, it is normally in the sole name of the employer or upper-tier contractor. In the end, the deemed trust may just be not much more than one of academic interest. 
Other problems such as delayed release of the retention and loss of retention in situations such as insolvency of the employer or upper-tier contractor are not unheard of. The recent unfortunate incident regarding a main contractor engaged in public works casts light on how these problems can evolve.

Study by the Queensland Building Services Authority has noted that reviews in New South Wales, Queensland and Western Australia have all recommended against such 'deemed' trusts because of serious legal shortcomings, a likely increase in the cost of building projects, failure to guarantee subcontractors will be paid, lack of industry support and high administrative costs.

In contrast, in some other jurisdictions, such as France and New Mexico, there is legislation requiring that all retention moneys to be held in a separate escrow account. 'Escrow' is a legal term which means money, goods or a written document, held by a trusted independent third party - that is, the escrow agent, pending the fulfilment of some condition (such as certification of practical completion or making good defects in the construction industry). A separate agreement is entered into with the escrow agent and the agreement to create the escrow account is often included as a term to the underlying contract between the parties.

As highlighted in the paper entitled Retentions: Striking out Cash Retentions published by the UK National Specialist Contractors Council in September 2007 (NSCC, 2007), most of the construction work, at least in the building services trades, is carried out by subcontractors. Hence, a substantial portion of the retention held by the employer does not actually belong to the main contractor; it belongs to the subcontractors that have built the job for the employer. This observation is equally true in Hong Kong. Some form of protection against lost of retention due to the specific circumstances of the main contractor should be provided.

However, it may be said that 'striking out retention' may be too drastic and may expose the employer or the upper-tier contractor to risks too great to bear. A means based on the current arrangements but striving to balance the interests of all the parties may be more acceptable.

The use of escrow account for retention money in the construction industry may have to include several features for it to become an effective solution. The retention money, instead of left mixed with the other funds of the employer, should be truly put in trust. This can be stipulated in the construction contract between the parties. The retention money will be automatically deposited into the stipulated escrow account. There can be various neutral third persons fit to act as the escrow agent. The usual escrow agents are banks or insurance companies. But in Hong Kong, the Construction Industry Council is probably best placed to provide such services at a small fee. Retention moneys from different projects between different parties will be put into separate escrow accounts managed by the Construction Industry Council, in return for a small administrative charge. The amount of the administrative charge may in whole or in part be offset by the corresponding interest earned from the deposits. The payer is responsible for paying in the retention into the escrow account under Construction Industry Council. The payer and/or the Construction Industry Council shall then send a notice of a payment-in to the beneficiary. If necessary, provisions can be made for the payer or the beneficiary payee to check the status of the escrow account with the Construction Industry Council. When properly operated, this arrangement creates a win-winwin situation for all and can be implemented within the contractual framework with only a minor modification.

\subsection{Certainty of interim payment}

It is widely recognised that poor payment practices in the construction industry give rise to substantial additional financing and transaction costs. It is therefore crucial to have certainty over how much and when payment is to be made. Such a theme is stressed in paragraph 2.8 of the Guidelines on Subcontracting Practice in Hong Kong (PCICB, 2003) and also paragraph 1 of the Guide to Best 'Fair Payment' Practices of the Office of Government Commerce in UK (OGC, 2007). Terms for achieving certainty of payment and timely valuation are good practices to be adopted.

4.3.1. Transparency in interim payment process (especially in nominated subcontracts arrangements). As a matter of fairness, there should be transparency in the interim payment process. Relevant information on each interim payment application and certification as well as payment times should be made available to the subcontractors. This will help develop certainty, confidence and trust within the construction pyramid ultimately for the benefit of the employer. This is important in the context of nominated subcontractors' payments which have to be by way of certification of the employer's engineer or architect. This is equally, if not more, important in the context of domestic subcontractors. They ought to be aware of the quantity/stage of works the contractor submits as having been completed thereby entitling them to interim payment, and what ultimately the employer has certified. There is no proper or justifiable reason why this should not be followed. One that has been proffered was commercial secret. Taken to its highest, it may justify redaction of information not relevant to the particular nominated or domestic subcontractor. For nominated subcontractors, the rates are often known to all. For domestic subcontractors, the relevant information needed is just the quantity/stage of works certified as having been completed. In any event, viewing the ground of commercial secret objectively and reasonably, it should not be sufficient to undermine the principles of fairness and transparency. After all, this mechanism is only focusing on interim payments, and would not affect the ultimate acceptance of the works.

\subsubsection{Reasons for withholding of payment to be expressed/clear timelines for assessing interim payments. Apart from transparency, the interim payment amount should fairly represent the works properly carried out or materials supplied, in accordance with the contract, and there should not be any unsubstantiated or disproportionate withholding of payment or refusal to value variations.}

Contractual provisions to achieve certainty of payment are equally important in Hong Kong and in jurisdictions with security of payment legislation. Indeed, in those jurisdictions, a series of provisions (in different levels of detail) governing the dates on which payments become due and procedures for obtaining such payments are provided for. As observed in Sir Michael Latham's Review of Part II of the Housing Grants Construction and Regeneration Act 1996 in 2004 (Latham, 2004), 
even with provisions ensuring security of payment, the problem of lack of certainty of payment still required to be addressed by, for example, modifying section 110(1) of the 1996 Act to ensure that the amount of payment is crystallised between the parties before the payment date. Certainty of payment is of particular importance in contracts where there is no certification by a neutral person, such as an engineer or architect. In such situations, the payment framework can fail to create a clear understanding between the parties as to what is the sum due. The importance of this is also observed in chapter 2 of the UK consultation paper entitled Improving Payment Practices in the Construction Industry: 2nd Consultation on Proposals to Amend Part II of the Housing Grants Construction and Regeneration Act 1996 and the Scheme for Construction Contracts (England and Wales) Regulations 1998 in June 2007 (DTI, 2007).

The Hong Kong PCICB Guidelines on Subcontracting Practice (PCICB, 2003), or its Guidelines on Standard Forms of Domestic Subcontracts for Basic Trades published in May 2005 (PCICB, 2005), or the UK Guide to Best 'Fair Payment' Practices (OGC, 2007) provide useful guiding principles to be observed in entering into a contract with a view to getting enhanced certainty in payment. Appreciation, adoption and further promotion of these fundamental principles are needed for the betterment of the Hong Kong construction industry as a whole.

To give effect to these ideas, it is submitted that the immediate dispute resolution mechanisms must be in place to avoid abuse as well as to enable genuine differences between parties to be resolved avoiding entrenchment of views which tends to jeopardise working relationship.

\subsubsection{Milestone payment. The milestone payment approach} effects interim payments with reference to the achievement of pre-determined progress milestones, such as completion of foundation or reaching, say, the fifth floor. This approach helps to ensure that payment and works progress stay generally predictable and consistent, linking interim payment to the project programme. Milestone payments are based on concepts different from those conventional construction works contracts which require the taking of interim measurements as the basis to effect interim payments in order to reimburse the contractor for the value of works it carried out. The need to dispute over measurement can be avoided. It also enables better planning and enhances predictability of cash flow for both the contractor and the employer at all stages of the project. Any undesirable use of 'front-end loading' of payments in tendering may be prevented by installed pricing restraints for the respective milestones.

Apart from providing improved certainty of project payments, the milestone payment approach also motivates the project team members to adopt a target cost contracting approach. Working together with provisions for retention moneys, the milestone payment approach can also reduce the need to argue about deductions withheld for defects. Variations have to be dealt with separately. A clearly defined procedure to deal with variations should be in place. Readiness to accept a variation is a variation and willingness to value and agree a price for it is fundamental. Such changes in the works can then be valued and its payment reflected in the relevant milestone payment.
In Hong Kong, the milestone payment approach has been adopted in some public projects for quite some time. These include the Hong Kong Mass Transit Railway Corporation (MTRC), the airport core programme contracts and a number of other major works contracts in the public sector.

Although the question on whether the milestone in issue has been reached is still open to arguments, past experience in Hong Kong indicates that a detailed stipulation as to what constitutes the attainment of the milestone should not be necessary. In other words, the fewer words used the better. This gives flexibility for the parties involved to deal with the matters in a commercial manner, for the overall benefit of the project and all involved. Naturally, if not properly administered, the flexibility is also open for abuse. But with proper safeguards such as provision for immediate dispute resolution mechanism, the issue of whether a milestone is reached can be decided promptly, avoiding delay of payment.

Hence, consideration should be given for wider use of milestone payments in Hong Kong. Indeed, this is so recommended in the Hong Kong CIRC report that 'the Government and other major clients should consider the wider adoption of the milestone payments approach so as to motivate contractors to deliver better performance'. The greater use of well-defined milestone payment mechanism to simplify the interim measurement and valuation process is also recommended in UK Guide to Best 'Fair Payment' Practices (OGC, 2007). It is considered that it will lead to greater certainty of payment, lower financing charges and reduced transaction costs. One may also add better working relationship and team-work leading to better quality projects.

\subsubsection{Statutory adjudication.}

(a) No available immediate dispute resolution mechanism. To give effect to certainty of interim payment, it is necessary to bring into place an efficient dispute resolution mechanism during the currency of the works. At the moment, most contracts still provide for arbitration after substantial completion of works while giving an option for the parties to mediate or adjudicate if both agree. Such contractual provisions are not conducive to security of payment. One party is perfectly entitled to refuse to mediate or adjudicate. Arbitration at the end is futile so far as maintaining cashflow is concerned. An unpaid contractor or subcontractor is left with little remedy save to continue to provide advance capital funding to complete the project for the recalcitrant employer or upper-tier contractor. The party who was unpaid by reason of the employer not honouring certificates may rely on the contractual termination clause, if any. However, since there is no general right at common law on a contractor to suspend or stop works even if interim payments are wrongfully withheld, the party who was unpaid by reason of under-certification is without remedy that is of any utility, and has often resorted to measures exposing itself to the risks of breaching the contract or infringing the law by not paying the workers.

It is important therefore to totally revise the current arrangement of resolving disputes after completion or alternatively to give the receiving party a statutory right to pursue its entitlement for the interim/progress payments at the material time. As this could not be achieved by contract, this may have to be by way of legislation. 
(b) Experience overseas. In jurisdictions with enacted legislation on security for payment, statutory adjudication is an essential element of the whole scheme. Experiences in these jurisdictions generally indicate that statutory adjudication is running without much dissatisfaction or complaints (Kennedy, 2006) and other jurisdiction is in the process of discussing whether to adopt statutory adjudication in the construction industry (Glaholt, 2005).

Each piece of legislation contains slight variations. There are differences, for instance, as to what can be referred to adjudication, how the adjudication process should proceed and conclude, and the enforcement and challenge procedures of a decision by the adjudicator.

In the UK, a party to a construction contract, as defined by reference to 'construction operations', has the right to refer a dispute arising under the contract for adjudication. In New South Wales, Queensland, Victoria and Western Australia, a party to a construction contract, as defined by reference to 'construction work', may commence adjudication essentially when there is a difference between the scheduled amount in a payment schedule (which is required by the legislation to be served when a claim of payment is filed), and the amount claimed if the payment amount claimed is not paid or paid in full. In Singapore, the provisions are similar to those in Australia. In New Zealand, the scheme resembles that in the UK but the meaning of construction contract is defined differently.

As to the initiation of the adjudication process, the UK and New Zealand scheme requires the giving of a notice of adjudication and the actual acceptance of the reference to adjudication; while the Australia and Singapore scheme only calls for an adjudication application to be made. A time period is prescribed within which an adjudication application must be made in Australia and Singapore, but not in the UK or New Zealand.

The provisions of the security of payment legislation of these jurisdictions also differ, inter alia, in relation to the duration of the adjudication decision or determination or the range of powers available to the adjudicator. In particular, there is a procedure for a claimant party in New Zealand to seek the approval of the adjudicator for the issue of a charging order in respect of a construction site owned by the respondent and, if the land owner of the construction site is also an associate of the respondent, the adjudicator may, upon request, also determine that the owner is jointly and severally liable with the respondent and may approve the issue of a charging order over the construction site owned by that owner.

In New Zealand and Singapore, there is also a review procedure for the decision or determination after the adjudication. In other jurisdictions, the challenge of the decision is brought to court. The judicial sentiments in various jurisdictions differ as to the extent of the need for strict compliance with due processes or rules.

It should be noted that almost all of this security of payment legislation is now under review. These reviews however mainly aim at improving the operational efficiency of the respective legislation by drawing on the experience after implementation. In the review of the New South Wales legislation conducted in 2004 (NSWDC, 2004), it was reported that
Review feedback indicated that the Act is bringing parties together early in a dispute and in many cases the parties are then settling their dispute without having to rely on arbitration or court action. While the submissions generally supported the reforms introduced by the Act a number of themes were raised for consideration to improve its operation.

The areas for improvements identified are more on legislative refinement or clarification, rather than on policy objectives. Examples of these include clarifying and rationalising certain definitions and requirements under the legislation; clarifying and reassessing some exemptions and limitations currently provided under the legislation; introducing additional provisions voiding unacceptable contract terms, similar to the current pay-when-paid provisions; standardising adjudication application processes; providing for the withdrawal, grouping and referral of adjudication applications; providing adjudicators with more time to undertake determinations; enabling adjudicators to deem an adjudication application invalid; addressing issues arising from court challenges; addressing concerns relating to adjudication fees; and introducing minimum adjudicator qualifications. Hence, there is overall support for the Building and Construction Industry Security of Payment Act 1999 in New South Wales (NSWDC, 2004), across all industry sectors and there continues to be widespread satisfaction with the Act.

Obviously, a more diversified approach to change can be expected to be forthcoming after further reviews are conducted and legislation is put into further practice.

What would be the right model, if at all, for Hong Kong is not an easy question to answer. However, to make statutory adjudication effective, there are several matters that need to be kept in mind.

Above all, for an adjudication scheme to be effective there must be certainty both as to the timing and amount of payment that a party is entitled to under a construction contract. This is in line with the universal principle of fairness that participants to contracts have the right to receive full payment for the works properly done within a reasonable time and without conditions, as advocated in, for example, the Model 'Fair Payment' Charter contained in the UK Guide to Best 'Fair Payment' Practices (OGC, 2007). The common engagement of conditional payment clauses such as the pay-when/if-paid clauses in subcontracts runs contrary to the very purpose of introducing security of payment legislation so as to achieve certainty and then security of payment. Their existence can render the statutory adjudication system ineffective in operation. The lower-tier subcontractors will not be able to benefit from the legislation if their contracts contain a conditional payment clause. The problems of unsecured and advance capital funding cannot be alleviated. For these and other reasons, conditional payment clauses are not acceptable or rendered illegal and unenforceable in the various security of payment legislations.

The situation of a pay-when/if-paid clause can feature in a traditional contracting setting, as well as in other project finance schemes such as private finance initiatives (PFIs) and public-private partnerships (PPPs). Under these schemes, paywhen-paid arrangements are commonly adopted. In the recent case of Midland Expressway Ltd v. Carillion Construction Ltd 
(No. 2), where an injunction was sought to restrain the adjudication proceedings, the Technology and Construction Court in the UK held, in relation to a PFI-type project for the construction of the tie-ins between the M6 and the new M6 toll road in UK, that provisions in a construction contract that restricted a contractor's right to interim payments to a proportion of the entitlement of its employer could be unenforceable for the reason that such 'pay-when-paid' provisions would be contrary to the Housing Grants, Construction and Regeneration Act 1996. Since such provisions have been widely used in PFI/PPP projects, the implications of this decision are considerable and catch the industry by some surprise. This is coupled with the usual arrangement in various security of payment legislation that the parties cannot, generally speaking, contract out such legislations.

In chapter 2 of the UK latest consultation paper on the subject (DTI, 2007), as part of the proposal to create a clear understanding of the sum due under a construction contract, it goes even further to consider whether to restrict the use of the traditional pay-when-certified clauses in construction contracts. Traditionally, in many contracts, certification by a supervising architect or engineer of payments is a normal and effective method of confirming sums due under the main contract. However, there are some concerns about lack of clarity when a subcontract uses the certification process under the main contract as part of its payment mechanism. One of the justifications for restricting this as suggested in the paper is that, usually, a subcontractor has no way of knowing whether a main contract certificate has been issued, or its contents, or whether the contractor has grounds under the pay-whencertified clause to withhold payment. The sentiment is a definitive move away from any form of conditional payment.

Adjudication, like all other dispute resolution processes, is liable to be abused. Hence, safeguards should be installed. In the various legislations providing for adjudication, the time frame is usually relatively very short for the respondent to consider the claim made and to prepare its response in the adjudication. This is one of the very characteristics of the adjudication process for a determination or decision to be made within a short period. Indeed that is necessary if one is dealing with disputes over interim or progress payments. For example, in Singapore, a determination of the adjudicator is to be made within just one week or two. Therefore, unlike the claimant who has more time to prepare its claim, the respondent is faced with a much shorter period. Yet, the amount at stake, even during the interim period, can be substantial. The concern of the respondent (payer) can nonetheless be addressed by the right of it to seek to reopen the decision by way of arbitration. This is often proffered to explain why this rough justice approach works and is beneficial. More importantly, the respondent would be well versed with the certificate it has just issued and should not be too seriously prejudiced by the relatively short time frame. However, if the claimant seeks to utilise and run the adjudication process as a final accounting exercise, then without safeguards, the adjudication process may be opened to abuse by a strategicallyminded claimant. The respondent may be deprived of a fair chance to properly defend the claim. Unlike interim payments, the final account process is usually triggered by the contractor putting in its draft final account for discussion. The respondent may genuinely need more time than the normally short statutory limits. If inadequate time is provided, it runs contrary to the spirit of fundamental fairness so far as the adjudication process is concerned.

One way to address this potential problem is to provide that final accounting exercise should not be covered by the legislative regime and the parties can move to arbitration. Alternatively, a different time frame should be used.

\section{PAYMENT TO WORKERS}

When dealing with security of payment, one should not of course lose sight of the need for safeguards for the frontline construction workers, who are even more vulnerable than subcontractors in many cases. They are at the foundation of the construction pyramid. They offer toil and sweat to the project before any payment is received even by the main contractor. Yet they are at the end of the 'food chain'.

Manpower is surely the most valuable asset in the construction industry. In Hong Kong, there is the wide adoption of the daily wage system of employment. Such a system of employment leads to unique kinds of problems when a worker seeks to recover outstanding wages. For example, a worker may be working for different employers during different days of the week; there is typically no formal employment contract in writing; some workers are actually engaged independent contractors rather than employees, being paid on a piece-by-piece basis for work done. Further, with such short-term and casual employment, it is not uncommon that wages paid to employees in statutory statement by contractors to the tax authorities are booked as expenditures rather than staff salaries. Hence, proving the fact of employment and the amount of wages outstanding is commonly the first matters in dispute at the Labour Tribunal.

Indeed, this daily wage system of employment is recognised as not being conducive to the development of a quality culture or talent retention and the industry has been urged to invest more in improving the quality of its workforce by providing a more stable employment for construction workers by widening the use of direct labour, starting with the core trades. Employers can assist through the contractual requirements of contractors using direct labour, and demand to see that a fundamental core group of workers has been engaged.

It should be noted that in some other jurisdictions, payments to workers may be regulated with statutory interventions to secure payments to workers. The New South Wales Industrial Relations Act 1996, for example, sets out the minimum wage and employment entitlements via 'industrial instruments', which include awards and enterprise agreements approved by the authorities. Employers are to provide employees with pay slips and keep records in relation to the employees. Failure to observe such mandatory obligations can result in criminal sanctions.

This extent of statutory framework and protection is not in operation in Hong Kong at the moment. In terms of providing protection for unpaid workers, Part IXA of the Hong Kong Employment Ordinance (Cap.57) has merely imposed a liability for head or upper-tier contractors to pay for a maximum of 2 months' wages of workers engaged by its lower-tier subcontractors for carrying out construction works on their sites should their actual employer fail to pay. Recently, wage disputes 
and wage arrears still have given rise to much concern over the past years in the Hong Kong construction industry. Due to the lack of knowledge of the identity of the subcontractor who engaged the unpaid workers, the innocent main contractor often ends up 'picking up the bill'. There may be a need to review this legislation in the not too distant future, whether in line with those adopted by the New South Wales Industrial Relations Act 1996 or otherwise. In the meantime, various measures to tackle the problems have been introduced.

The Construction Workers Registration Ordinance (Cap.583) is subsequently enacted. Its primary aim is to enhance the quality and skills of all construction site workers via assessment certification. However, it will also help combat employment of illegal workers and assist in resolving wage disputes between the contractors and the workers when coupled with the availability of site attendance records under the computerised smart card system and implementation of site entrance control measures (ETWB, 2005).

Following the publication of the Guidelines on Subcontracting Practice in 2003 (PCICB, 2003), the Hong Kong Government started implementing the use of the Subcontractor Management Plan in public work projects by the then Environment, Transport and Works Bureau in 2003, which can result in disciplinary actions to be taken against contractors who are in breach. Under the Subcontractor Management Plan, all contractors are required to submit with their tender, details of their subcontracting arrangements and to update the plan quarterly during the contract. This is meant to serve as a management tool for enhanced transparency of the individual contractor's subcontracting arrangement and accountability.

The PCICB has established the voluntary subcontractor registration scheme. Subcontractors who have failed to pay their workers may be disciplined or removed from the Registry. As a result, they may not be able to tender for jobs of major employers who all stipulate that only subcontractors on the registry will be accepted.

By this registration scheme and coupled with the subcontractor management plan, it is hoped that the frequent offenders of the labour law will gradually be rehabilitated or expelled from the market.

In public housing projects, a package of measures has also been introduced to require contractors to secure payments for workers on future Hong Kong Housing Authority construction contracts, which takes effect for all new building tenders issued after 1 May 2006 (BC, 2006). These new measures include the coupled use of electronic site access control, supplemented with workers' attendance records for cross-referencing with employment records; requiring workers' employment agreements and labour records for contractors and subcontractors; implementing a wage payment monitoring system and records, with payment by auto-pay; and implementing a subcontractor management plan where contractors must report all layers of subcontractors engaged on site.

With the introduction of auto-pay, situations of falsified allegation over self-employment and fabricated wage slips, or wage receipts signed under duress should be reduced. Proper safeguards or monitoring through management measures by the main contractor are obviously required to ensure wages due are indeed paid on time and on a regular basis. Initiatives from the employers are crucial to help change the culture of the industry and ensure security of payment all the way to the wage payments to workers.

\section{CONCLUSION}

Cash flow is the lifeblood of the Hong Kong construction industry. It is particularly important when the industry thrives on small subcontractors providing labour without any advance payment. The experience and systems in many jurisdictions outside Hong Kong in relation to the use of legislative and other measures to enhance the ease and security of payment can provide guidance and insights for considering the preferred path forward for Hong Kong.

Everyone agrees with fair and prompt payment practice. A fair payment culture underpins any advancement in a modern industry. However, what actually constitutes fair and prompt payment is the subject of considerable debate, and views differ depending on where the stakeholder in issue belongs within the structure of the construction industry. There is also no united voice on how to achieve it.

Through outlining and reviewing such options and alternatives, some views on their practicability and benefits for application in Hong Kong have been expressed. This analysis is by no means the conclusion of the subject. It is hoped that this will contribute to the further and focused study and discussion among stakeholders in the Hong Kong construction industry by providing a reasoned and objective foundation.

It is high time the construction industry in Hong Kong should review the question of security of payment, thinking more for the betterment of the construction industry in Hong Kong as a whole and less for one's own immediate or short-term interests.

\section{REFERENCES}

AustLII (Australian Legal Information Institute) (2009)

Construction Contracts Bill 2004 Explanatory

Memorandum. See http://www.austlii.edu.au/au/legis/wa/ bill_em/ccb2004294/ccb2004294.html for further details (accessed 23/12/2009).

BC (Building Committee) (2006) Chairman Report by the Chairman of the Building Committee for 2005/2006 to the Hong Kong Housing Authority. BC, Hong Kong.

Building and Construction Industry Security of Payment Act 1999 (1999) New South Wales Government, Sydney, Australia.

Building and Construction Industry Security of Payment Act 2002 (2002) Queensland Government, Brisbane, Australia.

Building and Construction Industry Security of Payment Act 2002 (2002) Victorian Government, Melbourne, Australia.

Building and Construction Industry Security of Payment Act 2004 (2004) Chapter 30B. Singapore Government, Singapore.

CIRC (Construction Industry Review Committee) (2001) Construct for Excellence: Report of the Construction Industry Review Committee. CIRC, Hong Kong.

Concorde Construction Co Ltd v. Colgan Co Ltd (1984) HKC 241.

Construction Contracts Act 2002 (2002) New Zealand Government, Auckland, New Zealand. 
Construction Contracts Act 2004 (2004) Western Australia Government, Perth, Australia.

Construction Industry Payment and Adjudication Act 2007 (2007) Malaysia Government, Kuala Lumpur, Malaysia.

Construction Workers Registration Ordinance (Cap.583) (2007) Hong Kong Government, Hong Kong. See http:// www.legislation.gov.hk/blis_pdf.nsf/ 6799165D2FEE3FA94825755E0033E532/ 03E2ED7691ADBBA1482575EF001F02DB/\$FILE/ CAP_583_e_b5.pdf for further details (accessed 24/12/ 2009).

Contractors' Debt Act 1997 (1997) New South Wales Government, Sydney, Australia.

Deng XM and Wang CY (2006) Analysis of tested effects and future development of employer payment bond system. Construction Economy 289: 5-8.

DTI (Department of Trade and Industry) (2007) Improving Payment Practices in the Construction Industry: 2nd Consultation on Proposals to Amend Part II of the Housing Grants Construction and Regeneration Act 1996 and the Scheme for Construction Contracts (England and Wales) Regulations 1998. DTI, London.

Employment Ordinance (Cap.57) (2007) Hong Kong

Government, Hong Kong. See http://

www.legislation.gov.hk/blis_pdf.nsf/

6799165D2FEE3FA94825755E0033E532/

277CODAA6FCB2973482575EE00348F4E/\$FILE/

CAP_57_e_gb.pdf for further details (accessed 24/12/2009).

ETWB (Environment, Transport and Works Bureau) (2005) Submission to Hong Kong Legislative Council: Measures to Monitor and Control Payment of Workers' Wages and Multi-layer Subcontracting. ETWB, Hong Kong.

Glaholt DW (2005) The Adjudication Option: Time for Uniform Security of Payment Legislation in Canada. See http:// www.glaholt.com/news/Adjudication\%20in\%20Canada.pdf (accessed 10/07/2009).

Home Building Act 1989 (1989) New South Wales Government, Sydney, Australia.

Housing Grants, Construction and Regeneration Act 1996 (1996) Elizabeth II. Chapter 53. Her Majesty's Stationery Office, London.

Industrial Relations Act 1996 (1996) New South Wales Government, Sydney, Australia.

Kennedy P (2006) Progress of statutory adjudication as a means of resolving disputes in construction in United Kingdom. Journal of Professional Issues in Engineering Education and Practice 132(3): 236-247.

Latham M (2004) Review of Part II of the Housing Grants Construction and Regeneration Act 1996 - Construction Act Review Working Group, Chairman's Final Report of the
Deliberations of the Payment Working Group. Department for Trade and Industry, London. See http:// www.berr.gov.uk/files/file30327.pdf for further details (accessed 24/12/2009).

LRCNS (Law Reform Commission of Nova Scotia). Builders' Liens in Nova Scotia: Reform of the Mechanics' Lien Act. LRCNS, Halifax, Canada.

MCPRC (Ministry of Construction, People's Republic of China) (2003) Report to the Standing Committee of National People's Congress on Implementation of PRC Construction Law. MCPRC, Beijing, China.

MCPRC (2004) Several Provisions on Implementing Construction Contract Guarantee in Real Estate Development Projects. MCPRC, Beijing, China.

MCPRC (2006) Notice on Opinion on Further Implementing Construction Contract Guarantee. MCPRC, Beijing, China.

Midland Expressway Ltd v. Carillion Construction Ltd (No. 2) (2005) 106 ConLR 154.

NSCC (National Specialist Contractors Council) (2007) Retentions: Striking out Cash Retentions. NSCC, London.

NSWOFT (New South Wales Office of Fair Trading) (2005) Report on the Outcome of the Review of the Home Building Act 1989. NSWOFT, Australia.

NSWDC (New South Wales Department of Commerce) (2004) Review Report May 2004 Payment Problems? Why Not Get Into the Act? Building and Construction Industry Security of Payment Act 1999 NSW (as amended in 2002). NSWDC, Sydney, Australia.

OGC (Office of Government Commerce) (2007) Guide to Best 'Fair Payment' Practices. The Stationery Office, London. See http://www.ogc.gov.uk/documents/ CP0159FairPaymentPractices.pdf for further details (accessed 23/12/2009).

PCICB (Provisional Construction Industry Co-ordination Board) (2003) Guidelines on Subcontracting Practice. PCICB, Hong Kong.

PCICB (2005) Guidelines On Standard Forms Of Domestic Subcontracts For Basic Trades. PCICB, Hong Kong.

RCBCI (Royal Commission into the Building and Construction Industry) (2002) Security of Payments in the Building and Construction Industry. RCBCI, Melbourne, Australia.

SCPRC (State Council of People's Republic of China) (2003) Notice of the General Office of State Council on Resolving Payment Delay and Default Problems in the Construction Sector. SCPRC, Beijing, China.

SCPRC (2004) Notice of General Office of State Council on Forwarding the Opinions of Ministry of Construction and Other Departments on Further Resolving Payment Delay and Default Problems in the Construction Sector. SCPRC, Beijing, China.

\section{What do you think?}

To discuss this paper, please email up to 500 words to the editor at journals@ice.org.uk. Your contribution will be forwarded to the author(s) for a reply and, if considered appropriate by the editorial panel, will be published as a discussion in a future issue of the journal.

Proceedings journals rely entirely on contributions sent in by civil engineering professionals, academics and students. Papers should be 2000-5000 words long (briefing papers should be 1000-2000 words long), with adequate illustrations and references. You can submit your paper online via www.icevirtuallibrary.com/content/journals, where you will also find detailed author guidelines. 